$\begin{array}{ll} & \text { Etnográfica } \\ \text { etnográfica } & \text { Revista do Centro em Rede de Investigação em }\end{array}$

Antropologia

vol. 11 (1) | 2007

Vol. $11(1)$

\title{
Determination and chaos according to Mozambican divination
}

Determinação e caos segundo a adivinhação moçambicana

\section{Paulo Granjo}

\section{(2) OpenEdition}

\section{Journals}

Electronic version

URL: https://journals.openedition.org/etnografica/1851

DOI: 10.4000/etnografica.1851

ISSN: 2182-2891

\section{Publisher}

Centro em Rede de Investigação em Antropologia

Printed version

Date of publication: 1 May 2007

Number of pages: 7-28

ISBN: 0873-6561; E-ISBN 2182-2891

ISSN: 0873-6561

\section{Electronic reference}

Paulo Granjo, "Determination and chaos according to Mozambican divination", Etnográfica [Online], vol. 11 (1) | 2007, Online since 25 September 2012, connection on 10 February 2022. URL: http:// journals.openedition.org/etnografica/1851; DOI: https://doi.org/10.4000/etnografica.1851

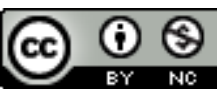

Etnográfica is licensed under a Creative Commons Attribution-NonCommercial 4.0 International License. 


\title{
Determination and chaos according to Mozambican divination
}

\section{Paulo Granjo}

\begin{abstract}
Although it is often assumed that the southern African systems of misfortune interpretation are deterministic, the notion of deterministic chaos seems to be more accurate to understand underlying principles of the Mozambican divination with tinhlolo. That system is based on a deterministic structure, it seeks to explain and to regulate the uncertainty, but its outcome is chaotic due to the complexity of the factors involved, unknowable in their totality and characterised by agency. To understand it as a domestication of aleatory system legitimates new comparison fields worldwide (including with the probabilistic notion of "risk"), and refocuses the study of Ngoma-like phenomena, from their reproduction mechanisms as affliction cults to their underlying logics and world visions.
\end{abstract}

KEYWORDS: divination, tinhlolo, deterministic chaos, risk, uncertainty, Mozambique.

DURING A RECENT CONFERENCE ON AFRICAN DIVINATION,${ }^{1}$ THE ETHNO-mathematician Ron Eglash addressed a paper that caught much my attention.

Stressing a contrast, he suggested that in North-Amerindian farming cultures the games of luck, divination systems and crop choices are based upon randomness, while in several African areas divination, games and fertility notions correspond to the model of "deterministic chaos" (Eglash 2005).

With this study in mind, I examined my Mozambican data, and what at first occurred as an abstract half-mistake, in the end, revealed itself to be accurate from the perspective of how people live daily. Since then, this notion has continuously crossed my mind, as the kind of idea that our intuition claims to be pertinent to our work, although we cannot clearly say why or how. 
In a way, this paper was written in the service of solving this dilemma of mine and, by doing so, to clarify the consequences that the deterministic chaos point of view brings to the study of divination and, more broadly, to the study of Mozambican notions and practices concerning the domestication of uncertainty. ${ }^{2}$

I will therefore discuss my examination of the Mozambican tinhlolo divination set, its contextual use, its practitioners and the underlying misfortune explanation system inherent in it, confronting this with the principles of determination, happenstance and deterministic chaos.

I will then suggest that, although such systems of uncertainty interpretation like the Mozambican used to be considered deterministic, they indeed present striking similarities to the "techno-scientific" system of probabilistic risk, including the kind of limitations they face and the reasons for those limitations. To classify them as deterministic would not only be incorrect, it would also be a waste of the explanatory potential of the data.

\section{THE MOZAMBICAN TINHLOLO}

The most common divination set in southern and central Mozambique, the tinhlolo, is not at all immutable, or even steady. By comparing contemporary sets with older examples as cited in reliable references (Junod 1897; Junod 1996 [1912]; Earthy 1933), it is evident that the divination set has changed distinctly over time; some variations between different sets are also observable today.

The reason for that variability comes, in part, from the fact that tinhlolo does not have ascribed to it a power in and of itself, nor a life of its own - altough the opposite situation may happen with other African divination sets. ${ }^{3}$ The diviners' metaphors about its nature ${ }^{4}$ may present it, complementarily, as an instrumental "perception amplifier", as a device that compels the spirits to meet their responsibilities and acts as the starting point and catalyst of communication relations, as an encrypting system, as a means through which the spirits can speak with a clear voice, and can even act as a kind of "playground" for them; but, ultimately, the tinhlolo pieces are assumed to be "things that represent things", functioning

2 The precise content of "deterministic chaos" and "domestication of aleatoriness" (as I prefer to call what was just mentioned as domestication of uncertainty) will be explained presently. A first attempt at analysing this issue was undertaken at an ICS brown-bag seminar (January $10^{\text {th }}, 2006$ ) and I wish to acknowledge those in attendance for their most stimulating questions and comments. I am also grateful to Maria José Arthur, Cristiana Bastos, Rafael da Conceição, Ron Eglash, Ana Loforte and Philip Peek, for their critical reading of the manuscript.

3 For a recent and fascinating example of this, see Silva (2004).

4 For a deeper presentation of this issue and the metaphors attached to it, see Granjo (2005b). The empirical basis for this article comes from conversations with diviner-healers in Maputo and Gaza provinces (from where the subsequent citations have been collected) and from the observation of divining sessions performed during 2004 and 2005. I wish to acknowledge all of these individuals with very special thanks to Job Massingue. 
effectively "as far as the diviner and his spirits know which one is which". Consequently, it is acceptable to utilize a new object to represent an entity usually symbolised by some other one, or to introduce innovative entities or situations into the divination set, which are necessitated by changing social conditions.

Nevertheless, we can say that, for the time being, there is a kind of standard tinhlolo in Maputo and Gaza provinces. In its complete version, it actually includes three different sets (figure 1).

Two of the sets are considered by their users to be variations of the same divination set and method, which existed prior to the Nguni invasions of southern Mozambique in the nineteenth century. ${ }^{5}$ Both have six similar elements: in one case, the so-called tinguenha, the pieces are crocodile back scales; in the other, the thiakata, they are nut shells from a tree called nulu, which plays an important role in the treatment of people diagnosed as spirit-possessed. ${ }^{6}$ They

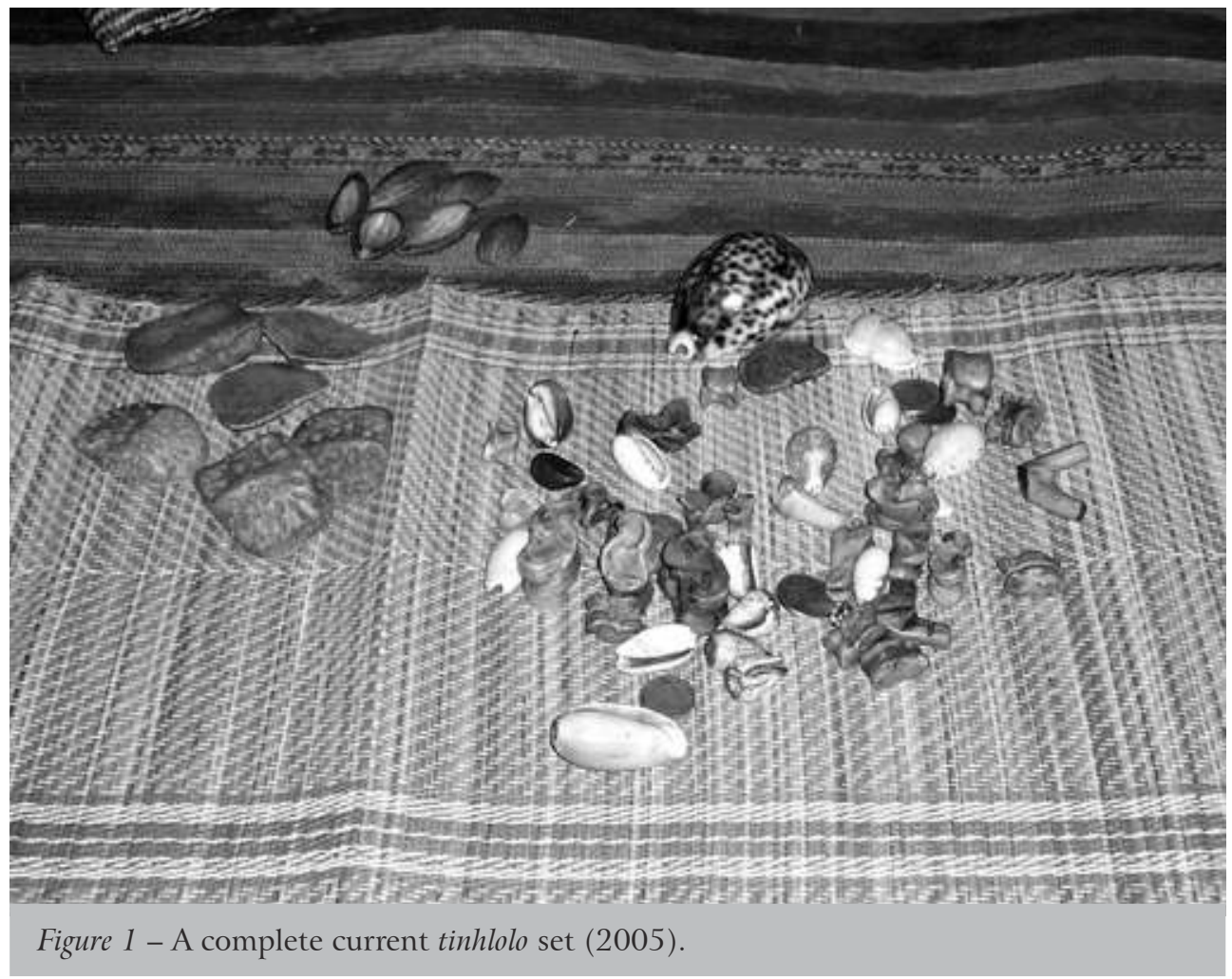

5 About the rise, assimilation policy and fall of the Gaza empire, resulting from that invasion, see for instance Neves (1987) [1878], Clarence-Smith (1990) [1985], Liesegang (1986), Pélissier (1994) and Vilhena (1996).

6 The leaves of this tree are crushed and macerated in water, then shaken until a large amount of foam is obtained. The patient must drink that foam three times a day, in order to appease his spirits' impatience during the education to become a future diviner/healer. 
also have in common the classification of their elements as three males and three females, and share the same principles of divinatory reading. The latter is based on the number and gender of the elements that fall with the "up" or "down" side visible, on the geographic direction to which they point, and on the lineal combinations that they draw.

These two sets are described as "the most traditional ones", and diviners often claim their ancestors "only needed one of those sets to make a consultation". There is a polemic however as to which kind of set was used by different diviners in the past. Some diviners claim that only active warriors owned the tinguenha, while others consider it associated with the possession by spirits considered to be "from water", and a third group says that the determining use factor was mostly geographical: if the diviners lived close to a river, they would use the tinguenha; otherwise, they would own nulu nut shells. As will briefly be discussed, today, these sets are used for redundant confirmation on the first throws of "important consultations", and as independent sets when it is necessary to answer a client's direct questions. In the latter use, the set utilized - nulu or crocodile scales - depends on the spirit who "is working" together with the diviner in that particular session.

The third partial set of tinhlolo (the larger and more diversified set) is the set most recognizable in Junod's and Earthy's descriptions. Southern Mozambican diviners sometimes mention it as "Nguni tinhlolo", because it is believed to have a Zulu origin and to have been brought to the region by vaNguni invaders. ${ }^{7}$

This set is also composed primarily of male/female couples, including: eighteen cowries, four coins, two stones, the down side of two land turtles' carapaces, deformed seeds of canhu or its carved representation in canhu wood, and the astragalus of several animals, both wild and domestic. ${ }^{8}$ The domestic ones come from a male sheep - which stands alone because it represents the chief, and there's only one lineage chief - and nine goats, representing people of different gender, age and status. The wild animals' bones are said to come from chimpanzees, ${ }^{9}$ lions, kudus, gnus, impalas and a mountain gazelle.

An explanation of the divination meanings attached to each tinhlolo element and its reading principles would alone require a much longer article than this one. I want to emphasise, however, that the diviners are most aware of the variability

7 For "Nguni" and "Ndau", the plural is obtained with the prefix "va".

8 As Junod (1996 [1912]) already stressed, canhoeiro is one of the ancestors' possible shelter trees, and a much enjoyed beer of communitarian consumption is made with its fruit; he however preferred to omit that both the enjoyment of it and its collective consumption are connected with the aphrodisiac power ascribed to the drink. Besides those objects, dice are also becoming increasingly common, usually representing different kinds of spirits.

9 I have strong doubts about this identification, since biologists' references point out that the only great ape or monkey existing in Mozambique or near its borders is the baboon. Most diviners I know, though, used the word "chimpanzee". 
of those elements. As I heard repeatedly: “Those bones aren't really the way they should be, because each one of these things is connected with a certain animal. See: in the old days, if it was the muluve, the ancestor, you would have to use the wild boar bone. But today we use symbols [my emphasis] and collect the pieces as we can find them. Then, we give the name according to the needs."

So, if it is assumed that changing the pieces is not a problem (and that, in the end, it does not really matter what object is used), they also presuppose and evoke the existence of an archetypical era, an era when there was some natural or supernatural connection between the kind of animal that provided the bone and the social entity it represented during the divination process.

\section{THE DIVINER AND HIS/HER SPIRITS}

By now the reader must surely have noticed that, in the first initial pages of this text, I have already mentioned the diviners' spirits on several occasions. This is necessary as they are an inevitable reference in every conversation on the subject, since spirit possession is a local sine qua non condition for the practice of and ability for divination.

Indeed, one is not supposed to choose to become a diviner; one is chosen for that task by spirits who "want to work" through the diviner by the act of possession. The spirits select the chosen individual among his/her relatives, and they may be inherited from both sides of one's family. This is parallel with the social situation, where agnatic descent principles are predominant but not exclusive (Webster 1976), coexisting with sentiments and duties which arise from matrimonial alliances and endure for several generations, and with recurrent factors like bridewealth irregularities (Granjo 2005a) or the inheritance of one's personal name.

In exceptional cases, which I only detected in those families where a child's parents inherited a great number of spirits, ${ }^{10}$ the presence of spirits can be announced - through either divination or trance - even before a child is born, in conjunction with announcements of the baby's gender and name.

Normally, however, the spirits' claim over a person will assume the form of a "calling illness" that, together with individualized manifestations, will usually include strong pains and a general weakness that biomedicine cannot apparently explain. If the person doesn't recognise the presence of the spirits, or refuses or tries to delay the call, systematic misfortunes, illness and death are expected to afflict his/her relatives.

10 The behavioural attributes ascribed to spirits are similar to those of "traditionalist" living people. As a rule, they do not prefer crowded host places/people, which potentially create conflicts among them, and will tend to "divide the village" between two subsequent generations, instead of waiting for the diviner's death in order to possess one of his/her grandchildren. 
This violent behaviour of the spirits is not ascribed to wickedness, but rather, to the limitations they face in their present form of existence. Although powerful (and the demonstration of power is also a conspicuous issue, here), they are merely "what remains" from the person they once were. For that reason, they are not able to communicate directly with the living, but are required to call attention to themselves indirectly, by causing abnormal and undesired events, in order to make themselves understood through the experts' divination or trance. Further, spirits who are not possessing anyone for the moment are believed to be "like children", and are considered to be given to a capricious and impatient attitude (Honwana 2002), especially if they find themselves impotent to transmit the message that they had hoped to transmit.

The result is a dynamic that fits well into the notion of the affliction cult (Turner 1968), although "cult" is perhaps not the best word to express the situation. The person afflicted by the calling illness will seek remedy from a diviner-healer and - once diagnosed as possessed by legitimate spirits who "want to work" - will only be able to circumvent the affliction by accepting to become a diviner-healer him or herself. Otherwise, he may die. The patient will then in turn become a therapist; and the oft semi-sceptical believer will now work as a practitioner who spreads belief. ${ }^{11}$

I here mention "legitimate spirits" and family factors, possibly suggesting that the legitimacy of a spirits' claim to compensation arises from its ancestor status, and that every ancestor is a spirit. In this context this is not the case.

On the latter issue, we may say that, if every spirit is an ancestor to someone (in as much as he/she has descendants), few ancestors become spirits. Everyone is believed to have a spiritual part which survives death and remains on Earth, protecting and correcting the behaviour of his/her descendants - descendants who have the duty to honour and submit to their ancestors, as they are supposed to do towards living senior kin. Nevertheless, only some of those spiritual "remains" achieve special powers, as a result of their exceptional spiritual strength, status or actions during life, or due to negative circumstances on their death. Only those are, in a strict sense, spirits.

Concerning the legitimacy of those spirits of a diviner who are not ancestors, it must be stressed that, on the contrary, the "full range" of abilities accessible to a diviner-healer depends on his/her possession by spirits of three different origins: ${ }^{12}$

Il In some cases, even recorded in books (Polanah 1987), it is possible to negotiate with the spirit(s) to select an alternative person to be possessed and, consequently, to become a diviner-healer. Putatively though, this is only possible when the spirit(s) manifest themselves for the first time inside one's family.

12 Although consensual, this classification doesn't exclude exceptional further integrations. For instance, I know a diviner-healer who claims to be possessed, in addition to others, by the spirit [continua] 


\begin{tabular}{ccc} 
Spirits' origin & Main ability and task & Complementary abilities and tasks \\
vaNguni & Divination & Cure \\
Tinguluve (ancestors) & Cure & Consultation/healing leadership \\
vaNdau & Kufemba (exorcism) & Divination \\
& Household leadership \\
\hline
\end{tabular}

As Alcinda Honwana suggested (2002), this division reproduces in "ethnic" terms the socially shared representations about the wars and the rise of the Gaza Empire, started in the early nineteenth century and defeated by the effective Portuguese occupation of the territory, in 1895.

Presented in words of my own responsibility, we have, on one side, the Nguni invader, who later become ruler, whose warfare and divination techniques kept an image of superiority that often match him to the leitmotiv of the civilizing hero, in folk and diviners' speech; second, there are the "owners of the land", those individuals who had been previously vanquished and assimilated by the invader, and owe their subsequent status and name to their submission: $;^{13}$ and finally, the Ndau, understood as the consistently resisting rebel, whose determination and endurance could only be explained by the presence of a strong spiritual power within him. ${ }^{14}$

However, in a different sense, the family also provides a legitimating principle for the integration of spirits whose origin is both outside the family or outside the region, following a logic of guilt and duty. Indeed, the legitimacy of a spirit's claim to possess and "work" derives from the relationship that he had with family ancestors when he was alive in the past. Typically, these legitimate spirits would have been, in the case of vaNguni, a close friend of an ancestor, or an ancestor's master who did much to help the family and now has no more descendants; and, for vaNdau, the spirit could be a woman who was brought from the war as a slave and concubine, could be her slaughtered relatives to whom she showed the way, after her death, to the house of the conquerors who kept her as slave, or could be an unmarried warrior who claimed a living

of a man with Luso-Indian origin and no kinship ties to his family. I was myself diagnosed as a future spirit, after my death, although I'm classified as a European without previous family connections to Africa. 13 The name of the larger linguistic group in southern Mozambique is "Changana", deriving from the expression "servants of Shangana", the political name of the first Gaza emperor.

14 In some accordance with its political base, this kind of classification was recuperated and emphasized during the long civil war that ended in 1992 and since then has been manipulated in regionalist claims - which sometimes even use the expression "Zulu colonialism" (Florêncio 2005). Besides, the civil war is often mentioned by diviners as "the spirits' war", in parallelism to Geffray's (1991) analyses. Notice also that the Portuguese tend to be considered strong spirits, in a direct but implicit explanation of Gungunhana's defeat and the subsequent colonial domination. 
wife from his killer's family and eventually decided to work, when his rage was appeased. ${ }^{15}$

Independent of the origin of the spirit, the ontological outcome of the possession remains very much the same. Although the spirit doesn't constantly remain in a person's body, both the spirit and the living individual are supposed to cease being the separate entities that they were, to become a joint symbiotic being, with a new and common identity. In this way, each influences the behaviour and identity of the other, a process that is learned as the two come to coexist during their training to become a diviner-healer. Indeed, a local dogma states that it is the spirit (and not his/her host) who is trained to work, because his/her knowledge has been forgotten since the death of the previous host; if the person should also learn along the way, this is a result of the symbiosis between the two.

A final characteristic to keep in mind is that, as Harry West (2004) eloquently points out in the case of northern Mozambique, the diviner-healers are not limited to repetitive traditionalistic speech or practice. On the contrary, their practice includes experiments, speculations and innovations, and they are eager to receive external recognition for their work, and attempt to improve their practice by learning outside knowledge with possible pertinence to their work - an external knowledge that may well be an asset in gaining and maintaining current clients.

\section{THE CONSULTATION}

In the context of the above conceptual framework, the "consultation" - as the divination session is termed in a deliberate analogy to medical science terminology - is seen as a communication relationship between four different agents: the diviner, his/her spirits, the client and his/her ancestors. ${ }^{16}$

Nevertheless, from the diviners' point of view, the consultation serves not only to gather information, but is also about gaining and keeping credibility with their clients. For that reason, their attitudes and the particular style with which they present their reading of the tinhlolo changes from person to person and from occasion to occasion, according to the diviner's level of confidence in his own reading and his strategy to instil confidence in his client. The sequence of the events in the consultation, however, is basically the same.

When a client arrives, he will merely ask for a consultation, without offering further specification as to his motives. Shortly thereafter, he will be invited to

15 Due to the performance of post-war cleansing rituals (Granjo 2006), the latter kind of claim isn't expected to happen during the killer's life. For that reason, healers are genuinely worried about an "epidemic" of spirits' claims in the next generation, when civil war soldiers will start to die.

16 Both clients and diviners may be men or women. Nevertheless, I will hereafter use only the masculine form (correspondent in the photos), in order to avoid systematic gender duplications. 
the hut belonging to the spirit who will lead the work that day, because the healer must request the spirits in a rotation, otherwise some "will get jealous, feeling that their work is not appreciated".

The diviner will then dress in that spirit's capulana ${ }^{17}$ and face his paraphernalia, calling the spirit to work by informing him that there is someone who seeks their help (figure 2). The spirit's agreement to participate is essential, otherwise the diviner "looks and only sees bones, but cannot read anything".

After invoking the spirit to the premises, a literate healer will write in a hospital-like register, taking notes on the client's official name, genealogy and traditional name - or, lacking a traditional name, his familiar nickname. In a country where many people do not know how to read or are not able to write anymore, this act - with obvious similarities to a Medical Doctor's routine - is usually practiced with circumspection and a share of solemnity.

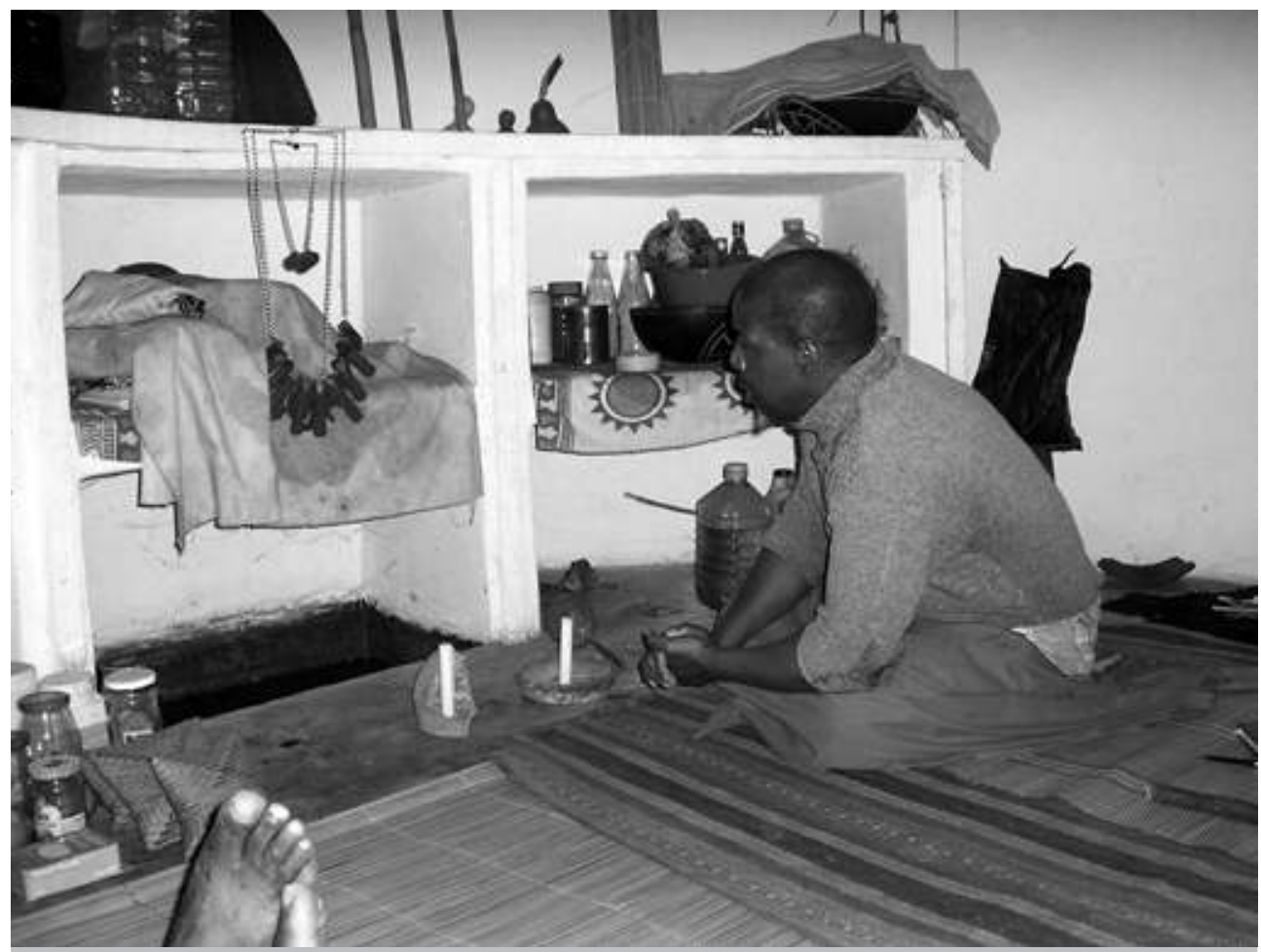

Figure 2 - Job Massingue, asking/calling one of his spirits to "work". ${ }^{18}$

17 Capulanas are local textiles usually rolled around the waist as a skirt, or used to carry babies at the loin. While working, diviner-healers use capulanas of a special design and colour, specific to the corresponding "ethnic" origin of the spirits who possess them, and usually own a different capulana for each one of their spirits.

18 The client was soon reprehended for keeping the feet in this position, which is feared to block the consultation. 
The spirit is then asked to make a kuvumbata (prophecy) for the client, who is identified by his name and ascendant kin back two or three generations. Subsequently, the diviner bites a branch of manono, a highly sour wood which helps him to induce what is usually called a "light trance", or a "mild trance" (figure 3).

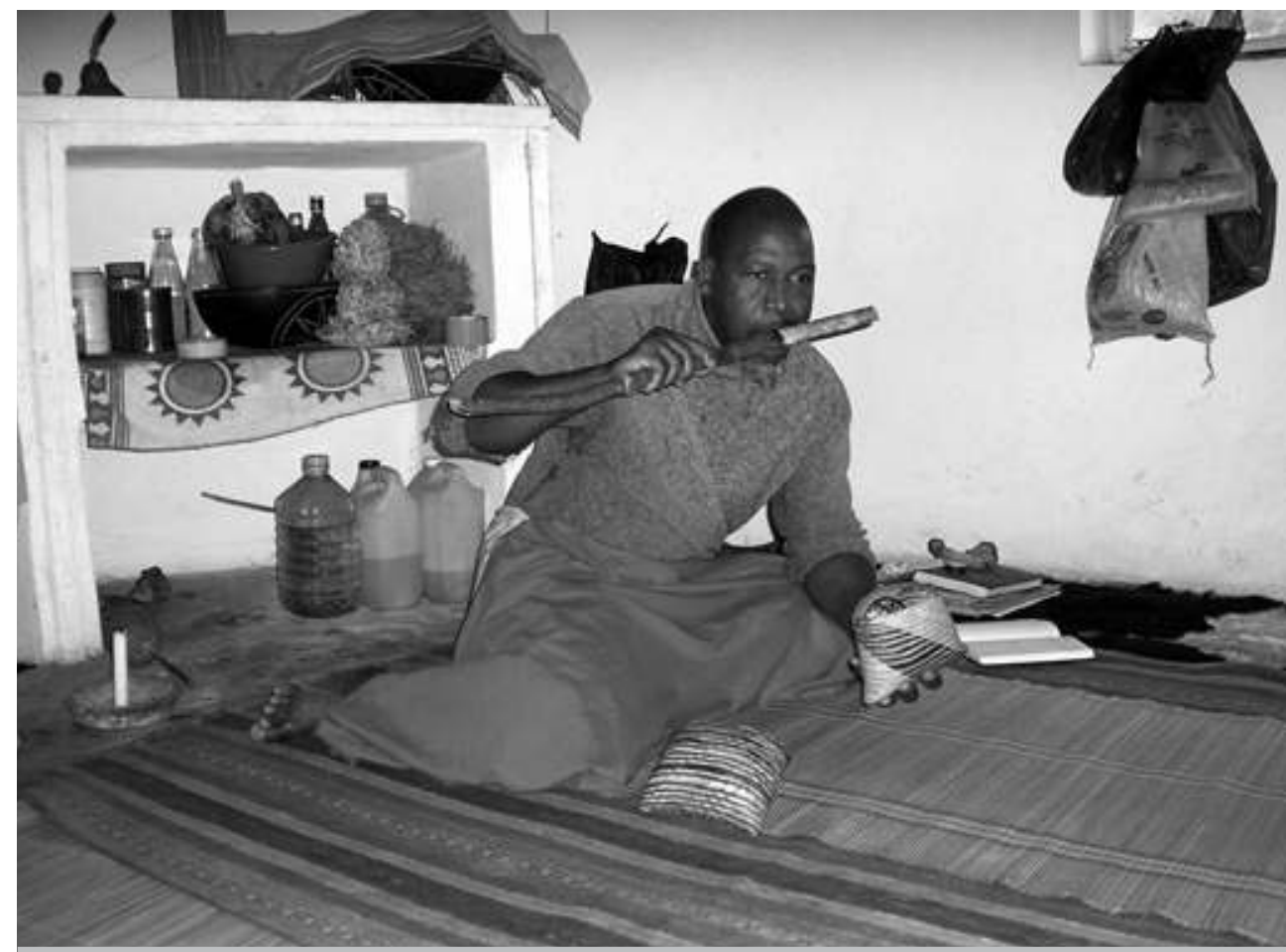

Figure 3 - Biting manono wood, to help inducing light trance.

Used in isolated circumstances, the word "trance" is indeed reserved for when a spirit takes complete control of the person and his movements, speaks through him and - according to a folk belief that several healers deny - makes him momentarily lose the perception of what is happening around him. ${ }^{19} \mathrm{It}$ is required that this state be achieved in several ceremonies and for the most spectacular type of kufemba (exorcism) treatments. In the case under description however, the spirits' incorporation into the diviner is rather described as a "shudder, and then like a light tissue over your shoulders".

19 Since the healer's subsequent question "What did he say? What happened?" is socially expected on such occasions, some diviners recognise that they themselves simulate that absence of consciousness, although they say that if their sensorial perception becomes different, it doesn't prevent them from having some basic notion of what is happening around them. 
Once the diviner feels the spirit's presence, he can throw the tinhlolo (figure 4). If he is already familiar with his client, he may use only the "Nguni" one; if it is a first or an important consultation (due to a client's high status or due to the expectation of a particularly complicated problem), he will normally "play it safe" by throwing both the crocodile back scales and the nulu nut

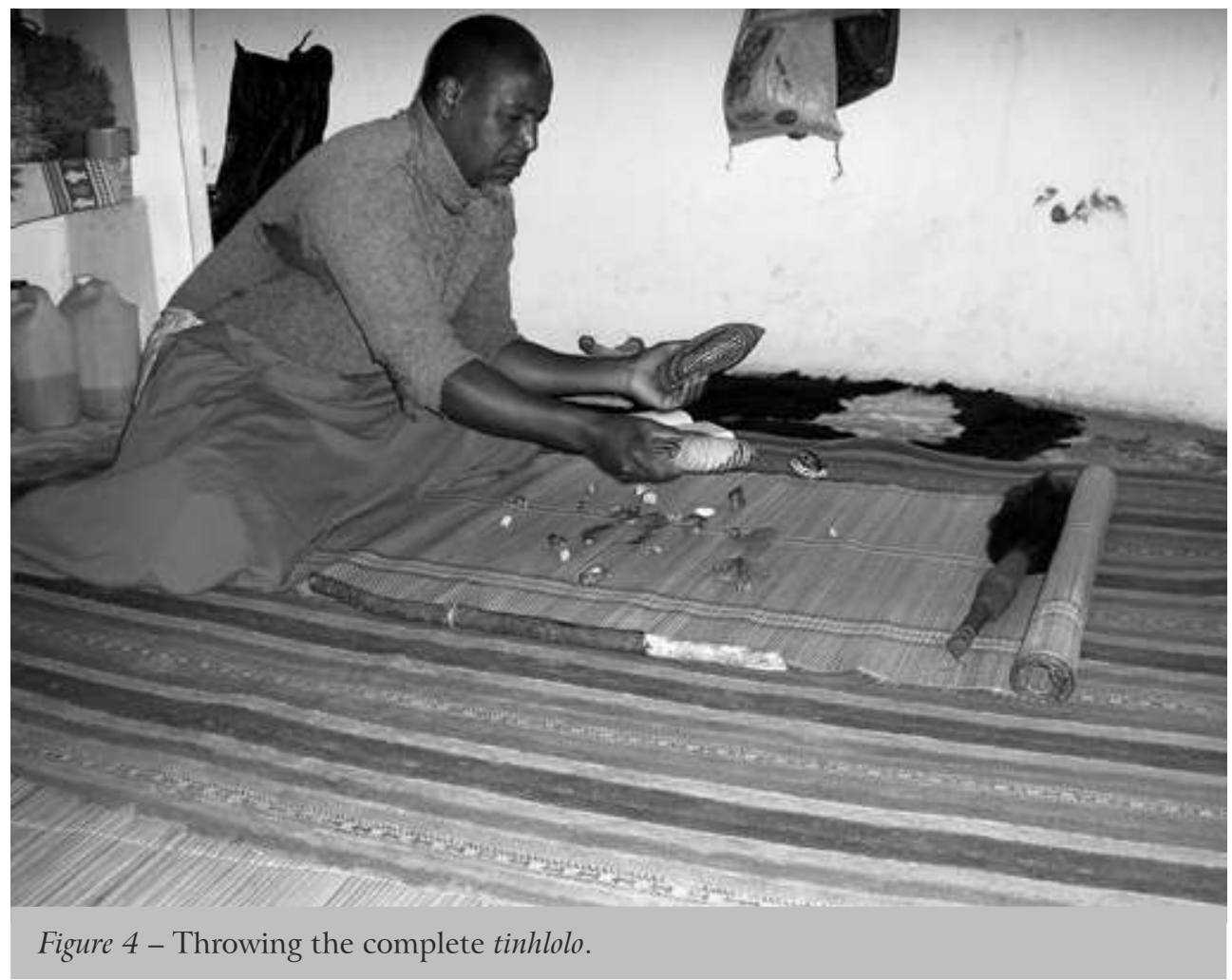

shells as well. The idea behind throwing all of them, is to compare the patterns drawn by the smaller sets with those of the larger and more complex tinhlolo: in a propitious consultation, the three sets should basically provide the same information; if they do not, something is not working correctly. Another value is that the simpler six-piece sets can help the diviner to focus his attention on the most pertinent information among the several reading lines provided by the larger set.

Prior to undertaking anything else, the diviner is supposed to identify the motive for a client's visit. If he fails to do so, the client will take his money back and leave. For that reason, most diviners are careful speaking in broad metaphors during this phase. Many of them will even "sing the tinhlolo song", a vague and broadly applicable story (learned from one's master) about the client's family and his past that more or less fits anyone from the population. 
According to how their client's react to the details of the story, the diviners progressively approach what they believe to be the issue.

The diviner's insecurity is legitimate, even by their own criteria. Indeed, besides the incorporation of the spirit, a good consultation is also believed to require that the spirit will be in a good mood and that his interaction with the client's ancestors will be mutually accepted. So even a good diviner can sometimes be unsure how or unable to provide true information; but, since his reputation is at stake, he will attempt to use his experience and observational abilities in order to arrive at the real issue.

If everything goes well, however, the situation is described in a different way. The diviner's interaction with the spirit is not, as they say, "somebody blowing what to speak into your ears", but is guided internally, like "things that come to your mind", "thoughts that flow inside your head". When the symbiosis between the diviners and their spirits is well achieved, and communication with the client's ancestors has been established, then - they claim - the tinhlolo pieces become almost secondary and no further throws may be needed:

"When that happens, no worries cross my mind about whether I am right or wrong, convincing or not. After a moment, I don't even look at the 'bones' anymore. The client thinks I'm looking and reading them, but I'm just talking, talking, talking, and without even noticing it I have already closed my eyes and I keep talking, talking, until I have no more to say. And when I shut up, normally there isn't really anything more to say, or to throw".

Such situations, however, do not occur with frequency. Commonly, the diviner will arrive at the problem, will explain its general reasons in a broadly metaphoric or a more direct way - according to his personal style and the confidence he feels (figure 5) - and will then wait for the client's reaction and commentary. The diviner will then ask the client several pertinent questions, and the client's commentaries and answers will lead to another throw - this time, however, the "Nguni" tinhlolo are thrown from his hands rather than from the straw bag where they are carried, ${ }^{20}$ as was done in the beginning.

What seems to be, to the observer's eyes, a therapeutic interaction - which also provides data essential to the diviner's interpretation and intervention - is, inside the divining profession, the object of two parallel explanations:

First, it is stated that while the issues raised in a throw are not completely answered, subsequent throws will only repeat the same information, without adding anything new. This redundancy arises from a main characteristic of the tinhlolo, as a medium of communication between spirits and the living, and is

20 In and of itself, the bag is not the object of any special concern. It is just a regular sipatsi bag bought in the market, as anyone else might buy, and if the bags are sometimes made with complex colour patterns, this is merely an aesthetic choice. Not even the material with which the bag is made is compulsory or signifies any special meaning: "We just buy what is for sale. Nowadays it is made of straw, but my grandfather, for instance, made his own in leather." 


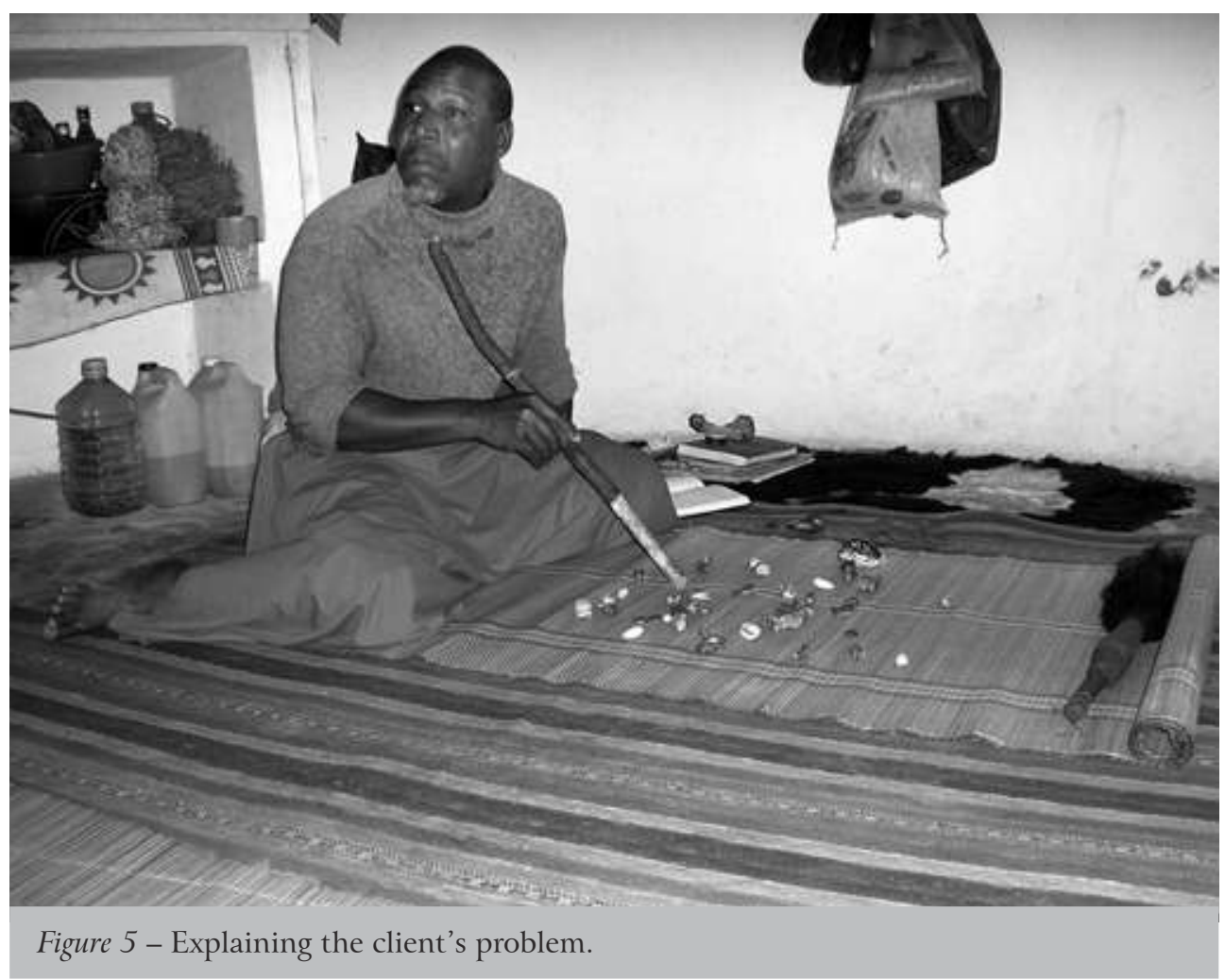

therefore subject to rules of common courtesy - as one must answer a letter, or an oral message, before receiving any return correspondence or communication.

Secondly, it is believed that when called upon, the spirits (especially if they are vaNguni) will only work effectively for a set period of time. After that, they become tired and the diviner will have to mobilize his own experience and observational abilities in order to complete the puzzle and the consultation - taking place in this way, the consultation is not kuvumbata anymore, rather it is "a guess", it does not matter how accurate it might be.

After several "Nguni" tinhlolo throws, however, the client may still wait for some direct answers, to clarify the doubts he had since the beginning of the consultation or that were raised during it. If this happens, the questions the client will ask cannot be dubious and must allow for a binary answer to be given, i.e., yes/no or dead/alive. One of the six-piece sets will then be thrown from the diviner's hands. Which one of the sets (tinguenha or thiakata), will depend on the preferences of the spirit who is working on that particular day and at that particular time.

At the end of the process one may notice that the conclusions of the main consultation were mostly presumed in the data that was confirmed by the client - as long as the data are interpreted according to the local domestication of 
aleatoriness system - and that an important part of the diviner's work is to make sense, in light of this, of those things that the client had already known. The client, however, will only confirm what was asked of him and, in the case of some diviners, will receive what amounts to a lecture on how local explanation principles work. In this way, his consultation experience does not just provide him with a sense of his misfortunes and a plausible way (most often ritualistic) to overcome them, but has also reinforced and given him a greater knowledge of cultural references, which, for such individuals, are usually fragmentary and vague notions. Additionally (in particular if the subject of the consultation is about family issues), the client may hear some advise about his behaviour, based upon the diviner's idiosyncrasies on social relations and assumed by him as a part of his role as counsellor.

\section{DOMESTICATION OF ALEATORINESS, DETERMINISTIC CHAOS AND MOZAMBIQUE}

But what is meant by the concept of domestication of aleatoriness; and further, what is meant by deterministic chaos?

When I first observed workers' danger management strategies at Sines oil refinery (Granjo 2004), it become clear to me how the probabilistic notion of "risk" is socially specific, and how strongly it induces the idea - from technoscientific speech to the surrounding society - that risk corresponds to the reality, and not to an attempt to give sense to such reality. ${ }^{21}$

I therefore needed to differentiate the objective potentially harmful factors (the "threats") from the different possible ways that they are conceived and represented according to diverse explanatory principles. By doing so, it is readily apparent that the possible conceptions about threat and uncertainty may vary between two extreme poles: on the one hand, the total assumption of the aleatory as something "real" and as the underlying principle to uncertain events (assuming the happenstance, to use a colloquial expression); ${ }^{22}$ and, on the other hand, its complete determination by extra-human logic or entities

21 In short, two different interpretations of the hazards - as probabilistic risks, or as unexpected, unpredictable and permanent dangers - contrasted in Sines according to a worker's position in the company's hierarchy, leading to two opposed attitudes on the resolution of technical problems. First the engineers' tendency to "take risks" in order to ensure production levels, legitimated their options with the idea of a low probability that an accident would result from the risks; and second, the precautionary tendency of all other kinds of workers - independent of their physical proximity to the hazards - to avoid exceptional actions that might induce instability or new dangers, was based on their knowledge about the mutability of technical conditions and the unpredictability of accidents. This non-probabilistic notion of danger is, meanwhile, imposed by the veteran workers onto the newcomers, during their informal process of professional training and integration.

22 Which leads to a conception of the threat of accident as "danger", i.e., as something totally unpredictable and unexpected in space and time, due to its randomness and to the complexity of the involved factors. 
(like divine will, fate, or the mechanical laws of a clock-like universe, for instance). Between those extreme points, there exists a continuum of conceptual possibilities, which have in common their attempt to ascribe sense and causality to the randomness and uncertainty that make them seen as knowable, regulated, explainable or even dominated by human beings. Those are domestications of aleatoriness (figure 6).

The position of deterministic chaos on such a continuum - or even at one of its extreme poles - is not evident.

Fundamentally, this notion states that to observers, the uncertain events are chaotic, but nonetheless have some underlying determination principle. In order to fully understand its implications, one must, however, keep in mind that the model for deterministic chaos is the mathematical equations which generate successions of numbers that do not correspond to finite cycles, ${ }^{23}$ and therefore never repeat as sequences, for often the individual results may repeat. So, although an instance of determination exists, the outcome is in fact chaotic, unpredictable and uncontrollable - unless one has access to the equation that generates the results.

When this notion is transferred to an interpretation of the uncertain outside world, its conceptual status - and its place in the continuum - ultimately depends upon the answer to three pertinent variables: i) what is the cognoscibility status ascribed to the "equation"? ii) is there any kind of entity able to know and manipulate the equation, and what entity is it? iii) is it possible to change the resulting events once the "equation" is known?

Depending upon the combination of answers to these variables, one may, indeed, be dealing with an aleatory-like chaos theory, with some deterministic system of religious or pseudo-scientific nature, or with different domestication of aleatoriness systems.

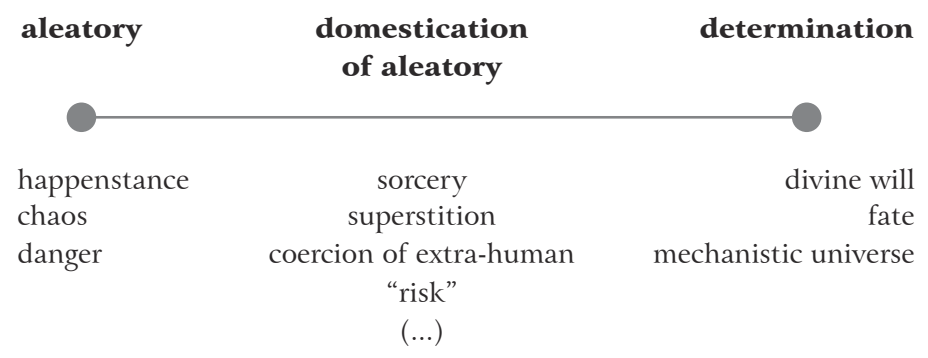

Figure 6 - Continuum of alternatives to conceive uncertainty and threat.

23 A classical example is the equation $P_{n+1}=R * P_{n}\left(1-P_{n}\right)$, where $P$ stands for a rabbit population and $R$ for its general rate of reproduction, when $R>3,56$ (cf. Eglash 2005). 
Is this the case of the dominant southern Mozambican system, which largely supersedes the country's borders? At first glance, the answer would appear unlikely.

The domestication of aleatoriness logic presiding over tinhlolo takes as its starting point the notion that randomness does not exist, nor do coincidences. For that reason, events which harm or benefit people presuppose an underlying cause, especially if they are recurrent.

Those underlying reasons, however, do not substitute nor do they stand in opposition to material causality. Indeed, it is considered that the world is full of material and natural hazards, which are ruled by material causes. Some of the logic of the hazards is known, some is not, but it is assumed that whether known or not, there is a logic that exists. ${ }^{24}$

If undesired events follow material causal relations, however, it is considered that they can only harm a person as a result of some social cause.

Moving down the checklist, the first potential cause may be as a result of the victims' own inability or negligence. If one is unaware of the proper way to do some specific action, if one has not had sufficient experience or training to do it correctly, or did not take the required precautions (that is, one is inadequate in what was attempted), then this will be the reason for the harm and no further inquiries will be necessary.

Other social causes can be blamed, if one was competent and careful, yet was nevertheless harmed by the undesired event. One reason of this kind is attributed to sorcery (normally ascribed to jealousy or other socially negative feelings or aims), which would attract one to danger, or distract one from sensing the existence and imminence of danger. ${ }^{25}$ The other reason could be a lack of protection from one's ancestors, which are supposed to provide protection from danger or alert one to it, yet failed to do so.

As noted above, this is the only way ancestors can communicate with an individual, so the next step would be to discover why they are displeased, and what can be done to correct what one has done wrong, or at least, to appease them. ${ }^{26}$

24 This is, I believe, one of the reasons for healers' interest in "foreign" knowledge, as well as for the use of some products that they include in their prescriptions due to metonymy. In several cases that inclusion does not seem to arise from a belief in the magical or symbolic power of the product, but rather from the assumption of as yet unknown (but still real) material causes.

25 Sorcery is also believed to act directly over material factors, but those diagnoses are relatively rare and usually limited to situations of intense social tension.

26 Also, a condition of good health is considered to be an individual's normal state, but one requiring harmony between the living, their social and ecological environment, and their ancestors. It is also jeopardised by one's carelessness, sorcery enacted by the living, or ancestors' displeasure, together with ecological dangers and the spirits' claim to "work". Even if the existence of "hospital diseases" is recognised and the local aetiological theories are often parallel to the academic ones (Green 1999), a physical manifestation of illness presupposes social causes. Consequently, it is not enough to treat [continua] 
Furthermore, the lack of protection on the part of one's ancestors is strictly a social issue, because its motivation comes from some social behaviour (from the living or from the past, when the ancestor was still alive), and because the ancestors are not extra-social entities, in that they do not live in some extra-human context. On the contrary, they are the "remains" of the beings they had been, and they live on the Earth near their descendants, upon whom they depend in order to be remembered, taken care of and honoured; and with whom they keep a relationship that follows the general rules of family protection and social control.

It is clear at this point that the divination and healing démarche where the tinhlolo is integrated follows a domestication of aleatoriness logic that is not original to Africa. In fact, despite the central importance of ancestors and spirits in this Mozambican explanation system, its general principles are similar, for instance, to Evans-Pritchard's classic interpretation of Azande witchcraft (1978 [1937]). It should be recognized however, that a consideration of a spirits' agency brings a far greater complexity to the system, and that the latter doesn't seek explanations for misfortune alone, but also for good fortune, along with other more complex issues, such as abusive behaviours in wealth redistribution (West 2005).

Limiting the analysis to the general data presented, one could also conclude that the notion of deterministic chaos is only partially pertinent in this conceptual context. Indeed, the outside world seems to follow a logic of deterministic chaos; but the relationship between the world and people does not - rather, it seems to be led by determination, although with a human or human-like base that transforms it into a domestication of aleatoriness form.

\section{DIVINATION AND "RISK"}

The application of this system's principles to real life, however, is less direct than we might presuppose from its general presentation, which is due to the recognised complexity of the factors involved in social relations.

Indeed, if a deterministic system were under analysis, it could be expected that one who is always careful, always comports himself in a socially appropriate manner with the living, and always acts according to his ancestors' rules would be considered to be safeguarded from unpleasant surprises. This, however, is not the case.

Among the living, even consistently correct behaviour can become an object of envy - and, therefore, the motive that is most often ascribed to have made one a victim of sorcery, both in order to retaliate or as a mean to appropriate another's qualities and strength. 
In one's relationship with the dead, there are also several possible reasons that one might be victimized, independent of one's exemplary conduct. For example, if, while commenting on one's actions, a drop of saliva were to fall from the mouth of a senior kin, one's ancestors would consider that event to be an invocation and the senior kin's comments would be taken as a request to correct the behaviour, even if that had nothing whatsoever to do with the kin's intentions when they were spoken. It is also assumed, and often diagnosed by diviners, that a spirit may be demanding compensation for a deceased kin's past actions. Finally, one may also be afflicted, not because of one's own actions or omissions, or even because of a guilt inherited from a deceased relative, but rather as a way to cast blame upon the one who is actually at fault - in this case, some close relative.

Therefore, this domestication of aleatoriness system is based on a deterministic structure, it seeks to explain and regulate uncertainty, but its outcome is chaotic due to the complexity of the involved factors, unknowable in their totality and characterised by agency. Coming back to our mathematical metaphor, the existence of an "equation" and the understanding of its elements is postulated, it is even sometimes assumed that the equation formula is known (at least by spirits), but it is impossible to simultaneously identify the value of all the incognita and, therefore, the equation result.

In short, the system adopts, in the practical application of its principles, a logic of deterministic chaos. ${ }^{27}$

By noticing the reasons why the system adopts that logic, one may notice striking similarities with the use of probability theory as a means to manage threat, under the notion of "risk". Indeed, the Mozambican system and probabilistic risk management face the same dilemma and for the same motives: although they both aspire to provide order to uncertainty and to achieve human domain over it, they both fail to control uncertainty prospectively due to the complexity of the involved factors - as a result, each turns prevention into only a partial palliative (Granjo 2004). This inability is highly pertinent, because, when we look at a domestication of aleatoriness system, it would be a fundamental mistake to separate its purpose in providing sense to events from its purpose in guiding human agency. If the existence of some sort of domestication of aleatoriness logic is a likely universal in human societies ${ }^{28}$, this

27 As Ron Eglash kindly underlined while commenting upon a draft of this paper, this is true because we do not face, in this case, many linear factors (which would turn the process into something complicated instead of complex, in random instead of deterministic chaos), but rather we face many non-linear factors, which interact in a way that changes their relation and individual evolution in consequence of their relational history (recall the classic example of water dripping over a Lorenz facet).

28 «Although many other forms of domestication of aleatoriness do exist, note that Philip Peek (1991:1) reiterates the pioneer inclusion, by George Murdock (1945: 124), of divination among the features found "in every culture known to history or ethnography". The existence of some sort of divination implies the existence of some sort of domestication of aleatoriness system.» 
is plausibly due to the necessity of surpassing the humiliation that arises from the meaninglessness of harmful events; however, the aim of a domestication of aleatoriness logic is never to solely provide a meaning to uncertainty, but to use that meaning in order to direct human action in an effective way.

Therefore, it is not enough to understand the logic and the epistemological status through which sense is provided; it is also necessary to clarify the potential, limitations and borders of its projection into the future as a guide to agency - it does not matter if the word used is "divination" or "risk analysis".

This similarity should thus call attention to the importance of some collective reflection about the practical consequences of "our own" hegemonic domestication of aleatoriness systems. ${ }^{29}$ However, since the issue is too large to deal with here, let us return to southern Mozambican divination, its underlying logic, and the consequences of what has been said.

One of the consequences is clear in direct observation, as well as through stated opinions and in the recounting of one's motives to seek a consultation: ${ }^{30}$ Mozambican divination is not a purpose in and of itself, but rather serves both to provide an order for events and a guide to action. This is relevant for the clients and is even more relevant to the diviner, who is also a healer of illnesses and social problems, and has through divination a means for diagnosis:

"Tinhlolo is like the MD stethoscope. It just makes things clearer, doesn't it? (...) It's the MD who must know the meaning of what he's listening to, and what he hears already exists without the stethoscope, it just helps. Tinhlolo is even more useful to us, because it's our stethoscope, our x-ray and our analysis all together."

When divination is examined, however, from a deterministic chaos point of view - an empirically accurate point of view as is apparent from this analysis - other issues become easier to understand.

The kind of utility of tinhlolo divination pointed out above immediately raises a new question: exactly what kind of answers is a consultation expected to provide? In other words, what status is ascribed to the causal relations disclosed and to the predictions made?

One thing is certain: consultation is expected to reveal more than just the future, and that future revealed is not expected to be sure and unchangeable.

29 I use "hegemony" in both Gramsci's (1971) meanings of group dominance achieved through subalterns' convincement by ideological means, and subalterns' acceptance and partial integration of the dominants' ideology.

30 Although several healers of my acquaintance are mostly sought out for their special expertise to solve a specific kind of problem, an informal accounting indicates that men mostly want to find a job, to solve professional problems, to overpass sexual impotency or to get girlfriends; while women mostly seek out the healers because of infertility, family problems, or in order to "fasten" [hold on] their husbands. Non-reproductive health problems are, in urban and suburban contexts, a less frequent reason for seeking consultation - with the exception of illnesses believed to be the object of a healers' specific expertise, such as asthma, epilepsy or aphthas. 
On the one hand, consultations with diviners are required to detect $a$ posteriori the underlying reasons for events and, in so doing, to make the events understandable, allowing for an effective reaction to them - through a correction of their ultimate causes or through protection against them. On the other hand, divination is expected to predict what is in one's favour and point out obstacles surrounding future projects, in order to allow accurate options, strategies and precautions.

In none of the cases - even those in which a specific divination may be considered to have given a true reading - will the diagnosed causes be unchangeable, nor will following a prescribed action automatically result in the expected outcome. The conditions for the current problems can be changed, and the future is not predetermined; but each individual action is just one factor among many others, which all interact and influence one another. Tinhlolo divination produces, in short, a conjuncture of frameworks of causes and relationships that leave room for a client's agency, but will also be influenced by the agency of many others.

One must thus contend with the notion of a regulated reality of such complexity that it becomes a lived uncertainty, where our ability to manipulate the underlying determination principles is not enough to safeguard individuals from harm, but one's ignorance about them would probably lead him to disaster.

This can be said of people's relationship with divination and, as demonstrated, it can also be said about the functioning of the conceptual system upon which it is based.

The most powerful consequence that the deterministic chaos point of view brings to the study of African divination and domestication of aleatoriness systems is, therefore, to warn against analyses that merely consider them to be deterministic practices and notions (as is generally done), prior to examining the issue in its depth.

By taking this new approach, it makes it more difficult for us to waste the complexity and comparative potential of our data, in two different ways.

In a broader sense, to understand ethnographic objects like the one here presented as being specific forms of interpreting uncertainty enlarges the pertinent comparative fields out from the relatively homogeneous space of the "Ngoma" phenomena (Janzen 1992). We also become able to equate other forms of domestication of aleatory systems worldwide, whether or not they are based on deterministic chaos, without falling into the logic of the "butterflies collection" criticised by Leach (1961).

Inside the "Ngoma" thematic area, meanwhile, this perspective stimulates us to focus our attention on the underlying worldview of the phenomena we observe - instead of, as is usually the case, emphasising their "affliction cult" characteristics, which ends up essentially reducing the whole system to its mechanisms of reproduction and legitimacy. 
This is not only a matter of labelling (or not labelling) a kind of phenomenon after one of its characteristics, which arises from a diagnosis that is indeed rare among those produced by diviner/healers. Once the focus stops being almost exclusively about how the spirits' possession verdict creates new practitioners, spirit possession itself regains its place as one of the possible explanations that belong to a wider, systemic and integrated logic of interpretation - which becomes much more understandable in its whole.

\section{REFERENCES}

ClarenCe-SMith, G., 1990 [1985], O Terceiro Império Português (1825-1975). Lisbon, Teorema.

EARTHY, E.D., 1933, Valenge Women. London, Oxford University Press.

EGLASH, R., 2005, An Ethnomathematics Comparison of African and Native American Divination Systems, <http://www.ccd.rpi.edu/Eglash/papers/eglash_div_paper.doc $>$.

EVANS-PRITCHARD, E.E., 1978 [1937], Bruxaria, Oráculos e Magia entre os Azande. Rio de Janeiro, Zahar.

FLORÊNCIO, F., 2005, Ao Encontro dos Mambos - Autoridades Tradicionais vaNdau e Estado em Moçambique. Lisbon, ICS.

GEFFrAY, C., 1991, A Causa das Armas em Moçambique: Antropologia da Guerra Contemporânea em Moçambique. Porto, Afrontamento.

GRAMSCI, A., 1971, Selections from the Prison Notebooks. London, Lawrence \& Wishart.

GRANJO, P., 2004, "Trabalhamos sobre um Barril de Pólvora" - Homens e Perigo na Refinaria de Sines. Lisbon, ICS.

—, 2005a, Lobolo em Maputo - um Velho Idioma para Novas Vivências Conjugais. Porto, Campo das Letras.

— 2005b, "It's just the starting engine: the status of spirits and objects in south Mozambican divination", <http://www.anthroglobe.info $>$.

—, 2006, "Back home. Post-war cleansing rituals in Mozambique", in B. Nicolini (ed.), Magical Practices, Witchcraft, and Warfare in the African Continent (XIX-XX Century). Lampeter, Mellen Press.

GREEN, E. C., 1999, Indigenous Theories of Contagious Disease. Walnut Creek, Altamira.

HONWANA, A., 2002, Espíritos Vivos, Tradições Modernas: Possessão de Espíritos e Reintegração Social Pós-guerra no Sul de Moçambique. Maputo, Promédia.

JANZEN, J.M., 1992, Ngoma: Discourses of Healing in Central and Southern Africa. Berkeley, University of California Press.

JUNOD, H., 1897, L'Art Divinatoire. Neuchatel, SGN.

—, 1996 [1912], Usos e Costumes dos Bantu. Maputo, AHM, vol. 2.

LEACH, E., 1961, Rethinking Anthropology. London, Athlone. 
Liesegang, G., 1986, Vassalagem ou Tratado de Amizade? História do Acto de Vassalagem de Ngungunyane nas Relações Externas de Gaza. Maputo, Arquivo Histórico de Moçambique. MURDOCK, G., 1945, "The common denominator of cultures", in R. Linton (ed.), The

Science of Man in the World Crisis. New York, Columbia University Press: 123-142.

PEEK, Ph. (ed.), 1991, African Divination Systems - Ways of Knowing. Indianapolis, Indiana University Press.

NEVES, D. F., 1987 [1878], Das Terras do Império Vátua às Praças da República Boer. Lisbon, Dom Quixote.

PÉLISSIER, R., 1994, História de Moçambique: Formação e Oposição 1854-1918. Lisbon, Estampa.

POLANAH, L., 1987, O Nhamussoro e Outras Funções Mágico-religiosas. Coimbra, Instituto de Antropologia da Universidade de Coimbra.

SILVA, S., 2004, Vidas em Jogo - Cestas de Adivinhação e Refugiados Angolanos na Zâmbia. Lisbon, ICS.

TURner, V., 1968, The Drums of Affliction: a Study of Religious Process among the Ndembu of Zambia. London, Oxford University Press.

VILHENA, M.C., 1996, Gungunhana no Seu Reino. Lisbon, Colibri.

WEBSTER, D., 1976, Agnation, Alternative Structures, and the Individual in Chopi Society, PhD dissertation submitted to Rhodes University, Grahamstown.

WEST, H., 2004, "Working the borders to beneficial effect: The not-so-indigenous knowledge of the not-so-traditional healers in northern Mozambique". Paper to the Social Anthropology Seminar of the London University College.

\section{Determinação e caos segundo a adivinhação moçambicana}

\section{Paulo Granjo}

Instituto de Ciências Sociais - Universidade de Lisboa

paulo.granjo@ics.ul.pt

Apesar de ser frequentemente assumido que os sistemas de interpretação do azar são determinísticos, pensamos que a noção de "caos determinístico" será mais adequada para compreender os princípios subjacentes ao sistema moçambicano de adivinhação através do tinhlolo. Este sistema assenta numa estrutura determinística, procura explicar e regular a incerteza, mas o seu resultado é caótico dada a complexidade dos factores envolvidos, desconhecidos na sua totalidade e caracterizados pela sua agência. Compreender o tinhlolo como um sistema de "domesticação do aleatório" legitima e amplifica o campo de comparação com outros contextos a nível mundial (incluindo a noção probabilística do "risco") e ressitua o estudo dos fenómenos do tipo Ngoma, dos seus mecanismos de reprodução enquanto cultos de aflição para as suas lógicas subjacentes e visões do mundo 